Columbia Law School

Scholarship Archive

1989

\title{
Coming of Age in a Corporate Law Firm: The Economics of Associate Career Patterns
}

Ronald J. Gilson

Columbia Law School, rgilson@law.columbia.edu

Robert H. Mnookin

Follow this and additional works at: https://scholarship.law.columbia.edu/faculty_scholarship

Part of the Business Organizations Law Commons, and the Law and Economics Commons

\section{Recommended Citation}

Ronald J. Gilson \& Robert H. Mnookin, Coming of Age in a Corporate Law Firm: The Economics of Associate Career Patterns, 41 StAN. L. Rev. 567 (1989).

Available at: https://scholarship.law.columbia.edu/faculty_scholarship/898

This Article is brought to you for free and open access by the Faculty Publications at Scholarship Archive. It has been accepted for inclusion in Faculty Scholarship by an authorized administrator of Scholarship Archive. For more information, please contact scholarshiparchive@law.columbia.edu. 


\title{
Coming of Age in a Corporate Law Firm: The Economics of Associate Career Patterns
}

\author{
Ronald J. Gilson* \\ Robert H. Mnookin**
}

The traditional American corporate law firm, long an oasis of organizational stability, in recent years has been the subject of dramatic change. The manner in which firms divide profits, perhaps the most revealing aspect of law firm organization because it displays the balance the firm has selected between risk-sharing and incentives, has changed in a critical way. From a long standing reliance on seniority that emphasizes risk-sharing, profit division is shifting to a system based on the productivity of individual partners that emphasizes incentives. ${ }^{1}$ With what seems to be only a short time lag from the change in how profits are divided, a second pillar of traditional corporate law firm organization is under assault. The "up-or-out system"- the long dominant career pattern by which employee (associate) lawyers are either promoted to partnership or fired-also appears to be changing. From a structure in which there were only two categories of lawyer-partner and associate-firms are creating new categories of employee lawyers, some with labels more euphemistic than others-permanent associate, staff lawyer, special counsel, non-equity partner, junior partner. Whatever the label, all flout the traditional career pattern by retaining associates who are not promoted to partner. ${ }^{2}$

\footnotetext{
- Professor of Law, Stanford University, and Visiting Scholar, the Hoover Institution.

** Adelbert H. Sweet Professor of Law, and Director, Stanford Center on Conflict and Negotiation, Stanford University.

(C) 1988 by Ronald J. Gilson \& Robert H. Mnookin. Research for this article was supported by a bequest from the Claire and Michael Brown Estate and a grant from the John $M$. Olin Program in Law and Economics. We are grateful to Robert Ellickson, Merritt Fox, Jeffrey Gordon, Leo Herzl, Stuart Kadison, Reinier Kraakman, Bayless Manning, Ian McNeil, Marshall Small, and participants in the University of Michigan Law and Economics Workshop, for comments on an earlier draft of this article.

1. See Gilson \& Mnookin, Sharing Among the Human Capitalists: An Economic Inquiry into the Corporate Law Firm and How Partners Split Profils. 37 Stan. L. REv. 313 (1985).

2. A number of the alternatives to the up-or-out system, both in nomenclature and substance, are surveyed in B. Heintz \& N. Markham-Bugbee, Two-Tier Partnerships and Other Alternatives: Five Approaches (Section of Economics of Law Practice, American Bar Association, 1986). For a discussion of the approaches taken by particular firms, see the sources referred to in note 54 infra.
} 
This change in the structure of corporate law firms presents two interesting questions. The first is why the up-or-out system was dominant for so long when, on initial analysis, it appears to work to the advantage of neither the firm nor the employee lawyer. ${ }^{3}$ On the one hand, the system forces the firm to fire lawyers simply because they are not thought qualified for promotion even though they may be performing competently (and profitably) at their present level. On the other hand, the system denies employee lawyers the additional career opportunity of remaining with the firm without being promoted, an opportunity that some may prefer to being fired.

If the historical dominance of the up-or-out system can be explained, the second question is what accounts for the seemingly sudden change in so central an element of law firm organization. What in the organizational environment has triggered the shift away from the upor-out system? In this paper we seek to answer these questions by understanding the economics of the implicit contract governing associate career patterns in corporate law firms.

\section{Introduction: Why Study Corporate Law Firms?}

As a preliminary matter, we should perhaps justify devoting attention to so arcane a subject as the career patterns of young lawyers who practice in corporate law firms. Two points bear making, one a quite general methodological concern about the use of economics to study organizations and the second a more specific concern over the growing importance of the service sector of the economy.

\section{A. The Methodology of the Nexus of Contracts Approach to Organizational Theory}

It is now commonplace among academics to regard the firm not as monolithic, but as a "legal fiction which serves as a focus for a complex process in which the conflicting objectives of individuals . . . are brought into equilibrium within a framework of contractual relations."4 The nexus of contracts theory claims that the firm will select an institutional structure that minimizes the "transaction" costs of organizing its activities. But this contractual approach to organizational theory has been subject to two important criticisms, both of which suggest that, while a useful heuristic, the theory runs the risk of becoming tautological with respect to the cost minimization claim. At the most general level, selecting so specific a focus as associate career patterns in elite corporate law firms is an effort to respond to these criticisms of a contractual approach to organizational theory.

The first criticism builds on the observation that the nexus of con-

3. See text accompanying notes 14-27 infra.

4. Jensen \& Meckling, Theory of the Fim: Managerial Behavior, Agency Costs and Oumership Siructure, 3 J. Fin. Econ. 305, 311 (1976). 
tract theory includes within its concept of contract more than traditional legal contracts. In a tradition pioneered by labor economists, voluntary relations, the terms of which are not governed by a detailed written document, are called implicit contracts. ${ }^{5}$ Legal academics, however, have objected to the use of the term "contract" to describe such relationships. ${ }^{6}$ They complain that describing a relationship as contractual is less a description than a conclusion. For these critics a contract has certain properties, particularly bilateral bargaining, that mark it as a voluntary trade, presumptively, if not conclusively, beneficial. Because the relations to which the term implicit contract is applied typically are not the subject of explicit bargaining, the term's use is criticized as conferring the imprimatur of contract on relations that do not deserve it. ${ }^{7}$ From the perspective of these critics, describing the relations within the firm as contractual suggests that the organizational patterns we observe, because "voluntary," are presumptively, if not conclusively, efficient. ${ }^{8}$ But this suggestion is unwarranted, the critics argue, because no meaningful bargaining occurs between the parties. And in the absence of meaningful bargaining, the efficiency of the observed relations within a firm has to be demonstrated rather than merely inferred from their existence.

A second criticism, voiced this time by economists generally sympathetic to understanding the firm as a nexus of contracts, expresses a parallel concern. It is easy to imagine a set of transaction costs for which any observed institution is an efficient outcome given the as-

5. See Rosen, Implicil Contracts: A Survey, 23 J. Econ. Literature 1144 (1985). Rosen credits Azariadis, Implicit Contracts and Unemployment Equilibria, 83 J. PoL. Econ. 1183 (1975), with coining the term. The simple intuition underlying the phrase is that the terms of the contractual bargain are not stated explicitly in a written contract, but are reflected implicitly in the substance of the continuing voluntary interaction between the parties.

6. See, e.g., Brudney, Corporate Governance, Agency Costs, and the Rhetoric of Contract, 85 Colum. L. Rev. 1403 (1985); Clark, Agency Costs Versus Fiduciary Duties, in Principals and Agents: The Structure of Business 55 (J. Pratt \& R. Zeckhauser eds. 1985).

7. For example, Brudney objects to a contractual characterization of the relationship between managers and shareholders:

It stretches the concept "contract" beyond recognition to use it to describe either the process of bargaining or the arrangements between investors of publicly held corporations and either theoretical owners first going public or corporate management. Scattered stockholders cannot, and do not, negotiate with owners who go public ... over hiring managers, over the terms of their employment, or over their retention.... Corporate statutes often prescribe that management will be selected by directors, not stockholders. At most, stockholders vote for directors, and they must rely on directors to act for them to hire and renew the "contracts" of managers. In that process, it is plain that stockholders have little knowledge and less choice in selection, retention, or determination of the terms of employment of either directors or executives.

Brudney, supra note 6, at 1412-13.

8. It is by no means clear to us why bargained for contractual relations-absent the pressure of competitive markets-should be thought of as presumptively efficient. There is much in bargaining theory to suggest that, particularly in bilateral bargains, the deal may or may not reach the Pareto frontier. See D. Lax \& J. Sebenius, The Manager as Negotiator (1986). 
sumed constraints. ${ }^{9}$ It is thus too easy to assume, rather than demonstrate, the efficiency of observed patterns of organization.

Both criticisms share a common core: that in the absence of detailed examination of actual institutions, the nexus of contracts approach to internal organization of firms risks being tautological or circular. Unless we learn something about the relationship between the existence of particular organizational characteristics and the presence of particular categories and magnitudes of transaction costs, the nexus approach, although a powerful heuristic, does not itself yield positive analysis. Working with a transaction cost approach to organizational structure in a rich institutional setting should illuminate the relationship between particular types and levels of transaction costs on the one hand, and particular organizational responses on the other.

\section{B. The Growing Importance of Service Industries}

Our focus on law firms also is motivated by an interest in firm organization in service industries. It is now familiar to note that the United States is fast becoming a service economy. ${ }^{10}$ Given the reported shift in the economy from production of goods to production of services, it becomes important to understand what happens to organizational structure when the firm's dominant input changes from industrial to human capital. Our premise is that this substitution of human for industrial capital causes problems of risk-sharing and incentives to take on special importance. The amplification of these problems explains much of the internal organization of service firms, as well as the rapid changes in form such organizations are experiencing. ${ }^{11}$

For a number of reasons, exploring the determinants of the organi-

9. Cf. Klein, Transaction Cost Determinants of "Unfair" Contractual Arrangements, in Papers and Proceedings of the 92nd Annual Meeting of the Amer. Econ. Ass'n, 70 Am. Econ. Rev., May 1980, at 356,362 (arguing that certain transaction costs might explain termination-at-will and exclusive-dealing clauses, but concluding that "ad hoc theorizing" must give way to empirical research).

10. For example, depending on the definition, services now employ two-thirds of the United States labor force, and growth in white collar and service occupations significantly exceeds employment growth in industry. Leveson, Services in the U.S. Economy, in Managing The Service Economy: Prospects and Problems 89 (R. Inman ed. 1985). Moreover, despite substantial balance of payment deficits in other sectors and significant barriers to international trade in services, the United States has become the world's largest exporter of services. Noyelle \& Dutka, The Economics of the World Market for Business Services: Implications for Negotiations on Trade in Services, in 1986 U. ChI. LEGAL F. 57, 62-63, 77-83. See generally V. Fuchs, ThE SERvice ECONOMY (1968).

11. We have in mind here not merely formal changes in structure, but major alterations in substance ranging from the recent rash of departures of the star performers of major investment banking and accounting firms, to the very disintegration of some major corporate law frrms. See, e.g., Berton, Andersen's Chief of Consulting Relieved of Role, Wall St. J., May 19, 1988, at 2, col. 2 (Arthur Andersen \& Co.); Berton, Arthur Young Sues 2 Partners, Alleging a Defection Scheme at Consulting Office, Wall St. J., May 27, 1988, at 4, col. 2; Shipp, Finle;, Kumble. Major Law Firm, Facing Revamping or Dissolution, N.Y. Times, Nov. 11, 1987, at A1, col. 3 (anticipated breakup of fourth largest U.S. law firm); Gilson \& Mnookin, supra note 1, at 314 n.4 (collecting examples). 
zational structure of service firms in the context of a professional organization has particular promise. First, because a law firm is a service organization whose most significant input is human capital, it seems a particularly useful lens through which to view the problem. ${ }^{12}$

Second, precisely because the dominant characteristic of a service business is the importance of human capital, detailed knowledge of (for lack of a better term) the culture of a particular type of service organization is critical to understanding the incentive structure actually in place. Particularly in professional service organizations, the ideology of professionalism has important symbolic consequences that must be integrated into the analysis. ${ }^{13}$ In this regard, the authors' personal experiences with corporate law firms provide important sources of insight.

\section{The Puzzle of the Up-or-Out System}

For a firm whose dominant input is human capital, the selection, training, evaluation, and retention of new employees is critical. In effect, these elements are a central aspect of the firm's capital budgeting process. The most peculiar aspect of the corporate law firm's capital budgeting process is the up-or-out system, which appears to have dominated employment practices over the entire period in which the institution of the modern corporate law firm has existed. ${ }^{14}$ This career pattern is easy enough to describe. Over a period of up to some ten years an associate progresses toward a decision concerning whether he or she will be promoted to partner. This status conveys lifetime tenure-i.e., job security until some retirement age-and the right to share in the profits of the firm. Until recently, this participation in many firms took the form of what we have called a sharing model in which profits were divided based on a lock-step seniority system without regard to

12. Changes in some service industries, however, have emphasized other assets. In investment banking, for example, changes in the capital markets, including the rise of merchant banking in connection with merger and acquisition activity, have resulted in an increased need for capital.

13. See, e.g., Nelson, Ideology, Practice, and Professional Autonomy: Social Values and Client Relalionships in the Large Law Firm, 37 STAN. L. REv. 503 (1985); Simon, Babbitt v. Brandeis: The Decline of the Professional Ideal, 37 Stan. L. REv. 565 (1985).

14. Inquiry into the origins of the up-or-out system credits its institutionalization to Cravath, Swaine \& Moore, one of the oldest, most successful, and most prestigious law firms in the United States. See R. Nelson, Partners with Power 72-73 (1988); M. Galanter \& T. Palay, The Transformation of the Large Law Firm 11-12 (Aug. 25, 1988) (paper presented at American Bar Foundation Conference on Professionalism, Ethics, and Economic Change, Sept. 22-24, 1988) (on file with the Stanford Law Review). Swaine's history of the firm indicates that the system was in place at least by 1916. Describing tine opportunity that is held out to a young lawyer by the firm, Swaine states that "[e]very lawyer who enters the Cravath office has the right to aspire to find his life career there-but only by attaining partnership." 2 R. Swaine, The Cravath Firm and its Predecessors: 1819-1948, at 7 (1948). It appears that permanent associates were a familiar element of law firm organization at the turn of the century, then declined steadily until the late 1960 s, by which point they had "largely disappeared." R. Nelson, supra, at 72; see M. Galanter \& T. Palay, supra, at 36. 
the actual productivity of any particular partner. ${ }^{15}$

The peculiar characteristic of this career pattern is what happens if the associate is not promoted to partner. No matter how close the associate may come to meeting the partnership standard, the associate is fired rather than retained as an employee. This result, at least at first cut, is difficult to understand from the perspective of either the firm or the associate. Simply put, the up-or-out system seems to work in no one's interest.

\section{A. The Puzzle from the Firm's Perspective}

The law firm's problem in devising an efficient career pattern for young lawyers is familiar in the labor economics literature. At the time of the initial hiring decision, the law firm is unable to tell which among its pool of new associates will come to possess the knowledge and personal attributes that the firm requires in a partner. The firm is uncertain not only about an associate's legal skills, ${ }^{16}$ but also about more subjective personal characteristics-for example, cooperativeness, maturity, the ability to gain respect of existing clients and to recruit new ones-that traditionally have been important to the partnership decision. ${ }^{17}$ Similarly, during the bulk of the period in which the modern corporate law firm has existed, firms have followed a sharing model of dividing their profits. The success of this model requires that partners have yet another subjective characteristic: a personal commitment to "professionalism"-an internally driven strong work ethic-that overcomes the absence of incentives in an income division method that emphasizes risk-sharing. ${ }^{18}$ The solution to the firm's uncertainty concerning how a new associate will develop is an apprenticeship: a period between initial hiring and the partnership decision that gives the associate the opportunity to demonstrate that he or she has both the legal skills and the personal characteristics for which the firm is looking. ${ }^{19}$

The apprenticeship period also provides an incentive for the associ-

15. Gilson \& Mnookin, supra note 1 , at $341-46$.

16. Even law teachers acknowledge that a student's performance in law school is a very noisy signal of her long-term performance as a lawyer.

17. For what are traditionally thought to be relevant partnership criteria, including "personal qualities," see Heintz \& Markham-Bugbee, supra note 2, at 32, 39. For a detailed and thoughtful analysis of "what you [an associate] should be doing to impress the partners of the firm, so that one day you'll be added to their number," see J. FrEUND, LAWYERING: A REALIStic Approach to Legal Practice 5 (1979).

18. Gilson \& Mnookin, supra note 1, at 374-79.

19. This account of the associate's apprenticeship period emphasizes the learning, as opposed to the incentive, aspect of labor contracts. The learning aspect posits that the process by which the employer comes to understand an employee's real productivity dictates the shape of the employee's earning profile. From this perspective, earnings are positively related to performance not because the compensation structure is designed to provide an incentive for performance, but because performance reveals the employee's actual productivity. This productivity becomes the basis for subsequent compensation. See Murphy, Incentives, Learming, 
ate to invest in firm-specific human capital-that is, human capital which has a significantly lower value if deployed outside the firm. $.^{20} \mathrm{Fa}-$ miliar human capital theory specifies that the firm must pay for the employee's investment in firm-specific human capital. ${ }^{21}$ The problem for the firm, however, is to assure that, after it pays for the employee's investment, it actually receives the returns. Once the employee has been paid to make the investment, the employee may be in a position to behave opportunistically by threatening to quit unless the returns from the investment are shared in a manner more favorable to the employee. A straightforward resolution of this problem is to pay for the employee's investment in firm-specific human capital by deferred compensation. Then the employee actually receives the compensation for acquiring firm-specific human capital only as, or after, the firm reaps the benefit of it. ${ }^{22}$ In the law firm setting, the promise of partnershipin effect, the right to share in the future returns from firm-specific capital ${ }^{23}$ - as compensation to those associates who successfully acquire firm-specific human capital serves to constrain employee opportunism. ${ }^{24}$

and Compensation: $A$ Theoretical and Empirical Investigation of Managerial Labor Contracts, 17 RAND J. ECON. 59 (1986).

Building on a learning approach, Holmstrom constructs an interesting model in which new employees work very hard because the greatest uncertainty concerning their actual ability exists early in their career. If working hard is treated by the firm as a favorable signal of their ability, then the marginal impact of (and return to) their effort is great in the early years of their employment because there is so little other information. As the firm learns more about the employee with the passage of time, additional effort has a smaller impact on the employer's overall assessment of the employee's ability and, as a result, the incentive for employee effort decreases with time. B. Holmstrom, Managerial Incentive Problems: A Dynamic Perspective (Mar. 1983) (unpublished manuscript on file with the Stanford Law Review). It is interesting that Holmstrom's extension of the learning model nicely fits familiar aspects of traditional associate career patterns. First, it is generally perceived that new associates work very hard, and that those who work the hardest are seen as the most promising. Second, and more telling, especially in the early years of employment, associate salaries are typically not subject to substantial variation based on actual performance. Thus, there is no short-term incentive aspect to the employment contract; the learning aspect seems dominant at this stage of the associate's career, at least with respect to current wages. For young associates in law firms, then, the anecdotal evidence suggests a result consistent with that found by Murphy, supra: learning dominates incentives as an explanation for the character of the labor contract.

20. Our analysis focuses, in particular, on the associate's investment in revealing to the firm her actual abilities. See notes 30-32 infra and accompanying text.

21. The seminal work is G. Becker, Human Caprtal 26-37 (2d ed. 1975).

22. See G. BECKER, supra note 21, at 29-31; Bulow \& Scholes, Who Owns the Assets in a Defined-Benefit Pension Plan?, in Financial Aspects of the United States Pension System 17 (Z. Bodie \&. J. Shoven eds. 1983); Lazear, Why Is There Mandatory Retirement?, 87 J. Pol. EcoN. 1261,1264 (1979).

23. Gilson \& Mnookin, supra note 1, at 353-56.

24. The two functions of the law firm apprenticeship period discussed in the text-facilitating the firm's learning about the associate's real attributes and providing the associate an incentive to acquire firm-specific capital-in fact blur in the middle, as is often the case when models are applied to the real world. If, as intuitively seems sensible, an associate's successful acquisition of firm-specific human capital is a function not only of incentive, but of the associate's ability as well, then the associate's success in acquiring it also provides information concerning the associate's abilities, a learning function. 
Thus, the employment pattern selected by the firm-an initial hire followed by a lengthy apprenticeship period before the partnership decision is made-makes perfect sense. The apprenticeship period serves to sort out the best and the brightest, provides an incentive for the associate to acquire the firm-specific human capital necessary for the firm's success, and constrains opportunistic behavior concerning the distribution of returns from that investment. ${ }^{25}$

What does not make sense, however, is the firm's behavior at the time of the partnership decision. Senior associates are a source of substantial income for the firm. ${ }^{26}$ Moreover, those associates who are still with the firm at the time a partnership decision actually is made already have been determined by the firm to be competent lawyers. ${ }^{27}$ Associates who lacked that level of competence would have been fired at a much earlier point in the apprenticeship period. Yet, a corporate law firm behaves very differently after making a promotion decision than other businesses. A law firm fires those associates it does not promote, rather than merely retaining them in the position in which they already have been shown to be competent and profitable. From the perspective of the firm, the puzzle is why it gives up the potential profits from con-

25. It is interesting that the apprenticeship period in corporate law firms is quite lengthy, generally no shorter than six years and not uncommonly as long as ten. In contrast, the apprenticeship of medical partnerships that use an up-or-out system is typically much shorter. For example, that of the Permanente Medical Group, the physician component of the largest and oldest health maintenance organization in the United States, is expected to be no more than three years. This discrepancy highlights a third function of the apprenticeship period in law firms. Law schools simply have not fully trained their graduates to be corporate lawyers, See Gilson, Value Creation by Business Lawyers: Legal Skills and Asset Pricing, 94 YALE L.J. $239,303-06$ (1984). Thus, in law firms the apprenticeship period must be long enough both to provide this additional training and to evaluate how effectively it has been learned by the associate. Post-medical school training of physicians, however, is provided by internship, residency, and specialty programs, taking from three to five years and generally completed before a physician joins a medical partnership. Thus, all that remains for the medical partnership's apprenticeship period is the learning function. It is notable that the apprenticeship period of a medical partnership together with the post-medical school training period is of a length comparable to the apprenticeship period of a law firm.

26. The explanation for the profitability of senior associates is familiar. By this time, the associate has completed his or her training as a corporate lawyer and the firm has learned enough about the associate's abilities and attributes to use them effectively. The associate then provides profit for the firm to the extent amounts billed and collected for the associate's time exceed the associate's salary plus related overhead. Partners debate vigorously precisely when associates become profitable. It is critical in evaluating the positions taken to keep in mind whether profitability is being determined on an average or marginal cost basis and to be careful in specifying what costs are marginal and over what period. However, the fact that differences among firms in associate/partner ratios explain a substantial amount of variance among firms in per partner profits, see text accompanying notes 48-51 infra, strongly suggests the importance of associate profitability. For a detailed discussion of the mechanics of nonpartner profitability in service firms, see Maister, Balancing the Professional Service Firm, SLOAN MGmT. REv., Fall 1982, at 15, 18.

27. The presiding partner of Cravath, Swaine \& Moore has acknowledged this point: "The most valuable persons in some ways to us are associates whom the clients are happy with." Getting Rid of the Simple Up-or-Out Partner-Associate Structure, AM. LAw., Mgmt. Rep., Sept. 1987, at 26, 30 (remarks of Samuel Butler). 
tinuing to employ the associate in a capacity other than partner. Why would the firm select an up-or-out system?

\section{B. The Puzzle from the Associate's Perspective}

Economic theory teaches that individuals are risk averse. Moreover, individuals are likely to be even more risk averse the greater their investment in human capital, which is difficult to diversify. Now assume that a prospective associate has a choice between jobs at two different firms. Both jobs have the same rewards for success-identical salaries and an identical chance of making partner after an apprenticeship period of identical length. The jobs differ, however, in an important respect: One of the jobs presents a risk the other does not. In one firm, associates who do not meet the standards for partnership are given the option of remaining in the firm's employ, but with no chance of ever becoming a partner. In the other firm, those who are not promoted to partnership are fired-the up-or-out system. Although one could understand that some associates who do not make partner would choose not to remain with the firm in a less than first class capacity, that result is hardly certain. Indeed, the possibility of remaining an associate simply increases the options available to the associate at the time that the firm makes the partnership decision. So long as there is any possibility that the associate might elect to remain with the firm as an employee despite not being promoted to partner, the option to do so is valuable. Thus, common sense suggests that, other things being equal, a job with a firm that offers the opportunity to remain an associate if one is not made a partner would be preferred to one in a firm that has an up-orout system. Why, then, might would-be associates willingly accept, let alone prefer, a firm that did not offer a consolation prize in the partnership race?

\section{A Framework to UnRavel the Puzzle: The Interaction of DUAL UnCERTAINTY}

The historical persistence of the up-or-out system is indeed puzzling if an initial pass at analysis suggests that both the firm and the associate are better off with a system that contemplates the possibility of retaining as an employee an associate who does not make partner. ${ }^{28}$

28. This does not mean a system that requires retaining all associates passed over for partnership or that gives associates who are retained some form of tenure. The need to attract new associates with the potential to become partners would counsel against retaining too many associates. Similarly, the need for flexibility to respond to changes in business conditions by reducing the numbers of "permanent" associates, rather than decreasing the inflow of new associates with partnership potential, would counsel against providing too much job security. What requires explanation is the up-or-out system's extreme position that, as a general rule, a firm never retains an associate who is not promoted.

The presence of some types of permanent associates is not inconsistent with this general rule. Cravath, Swaine \& Moore has a group of 24 specialist lawyers who will never be considered for partnership. However, these lawyers generally are not regular associates who were 
The puzzle from the firm's perspective is why it would fire valuable associates who did not meet partnership standards. The puzzle from the associates' perspective is why they would prefer a system that denied them the option of staying on as employees if they did not meet partnership standards.

This dual puzzle begins to unravel if one changes the time perspective. Our discussion to this point has focused on the time the firm makes the partnership decision about a particular associate. It is useful now to focus on the time when the associate is first hired. At this time the associate and the firm each face a different kind of uncertainty with respect to the associate's career path. ${ }^{29}$ The up-or-out system begins to make sense when considered as an organizational response to the two-sided uncertainty existing at the time the associate is initially hired.

\section{A. The Firm's Uncertainty: Associate Characteristics}

We have already described the uncertainty confronting the firm at the time the associate is initially hired. The firm cannot tell who among the pool of associates hired will come to possess the ability and personal attributes thought necessary to partnership. The organizational response to this uncertainty is an apprenticeship period during which, through their work, the associates both are trained and come to reveal their abilities. For this solution to the firm's uncertainty to be stable, however, it must be consistent with the associates' interests at the time of initial hire. The difficulty is that, without more, the organizational response to the problem of the firm's uncertainty itself creates the problem of the associates' uncertainty.

\section{B. The Associate's Uncertainty: Opportunism by the Firm}

The firm offers the associate the opportunity to spend seven to ten years working hard to become trained and to reveal to the firm his or her real abilities-a substantial investment in firm-specific capital. Those who do so and whose revealed abilities meet the firm's standards receive a large incentive payment: partnership. The associate's uncertainty at the time of initial hire is whether the firm will play fair at that future time when the partnership decision is actually made. Analysis of the law firm's incentives at the time of the partnership decision reveals substantial basis for associate concern. The firm has significant incentives to behave opportunistically in evaluating the associate's performance.

Consider the firm's position at the time of the partnership decision.

passed over for partnership. Rather, most "had been hired laterally with their specialties already in hand." Id. at 27 (quoting presiding partner Samuel Butler).

29. We owe this insight to C. KaHn \& G. Huberman, Two-Sided Uncertainty and "Upor-Out Contracts" (Hoover Inst. Working Paper in Economics No. E-86-47, 1986) (on file with the Stanford Law Review). 
The firm is making a substantial profit from the associate's labor. Promoting the associate to partner-paying off on the promise of an incentive payment if the associate makes the grade-rather than continuing the associate as an employee is costly to the firm; it diminishes the profits accruing to existing partners. At the same time, the associate is in a difficult position to insist that the firm keep its promise, because during the apprenticeship period the associate has made a substantial investment in human capital. Not all of this human capital can be easily transferred to other employers because it is "firm-specific."

The central characteristic of firm-specific capital is that it is worth significantly less in its best use in other organizations. ${ }^{30}$ An associate who has made a substantial investment in firm-specific capital is in an unenviable position at the time of the partnership decision. Suppose the firm opportunistically offers only a permanent associate position even though the associate actually has met the partnership standards. So long as the firm's non-partnership offer is more lucrative than what the associate could receive in alternative employment, an easily satisfied condition because the associate's firm-specific capital is by definition significantly less valuable to any other employer, the associate will earn more by accepting than by switching employers, despite the firm's opportunistic behavior.

Recall that the apprenticeship period responds to the firm's uncertainty concerning associate attributes by allowing the associate to reveal her abilities over time. This effort yields valuable information because an associate whose abilities are accurately known by the firm is a very different asset than one about whose abilities there is significant uncertainty. It is critical to a firm's successful practice that it know which associates can be trusted, which are adept at what types of work, which can deal directly with clients, and the like. Thus, an associate's value increases during the apprenticeship period as the firm learns about the associate's ability and, as a result, the associate requires less supervision and can be given more important work.

From the associate's perspective, the problem is that the information concerning her ability may be largely firm-specific. Because of an adverse selection problem, it cannot be easily transferred effectively to a different employer. ${ }^{31}$ If the associate tries to leave her current firm after not being promoted to partner, any other potential employer receives an obvious signal about the associate's abilities. The firm with

30. See, e.g., O. Williamson, The Economic Institutions of Capitalism 52-56 (1985); see also Gilson \& Mnookin, supra note 1, at 356-71 (discussing the character of firm-specific capital in a successful law firm).

31. See G. BECKER, supra note 21, at 27 ("Expenditures on acquiring knowledge of employee talents would be a specific investment if the knowledge could be kept from other firms, for then productivity would be raised more in firms making the investment than elsewhere."). To be sure, some increase in experience and legal knowledge can be cheaply verified by other firms. To this extent, the increase in the value of the associate's human capital is not firmspecific. 
the best knowledge concerning the associate's abilities declined to make her a partner. ${ }^{32}$ This information asymmetry concerning the associate's abilities between her existing employer and alternative employers thereby may turn even investment in ordinary legal skills, which otherwise would be general human capital because they are equally valuable in any legal position, into firm-specific human capital. Moreover, in addition to firm-specific capital created by information asymmetry, there are other sources of firm-specific capital. For example, knowledge of the firm's way of doing things, of the particular traits of firm lawyers, and of the firm's clients and working relations with such clients, all have aspects of firm-specificity about them. Thus, to the extent firm-specific human capital exists, an associate is disadvantaged in seeking alternative employment if the firm cheats on the partnership decision. She may then be left with little choice but to allow the firm to get away with it.

Our analysis thus far of the solution to the firm's uncertainty concerning associates' ability-an apprenticeship period with a promise of partnership to those who are successful-suggests that, without more, the solution may not work because of the associates' uncertainty. Indeed, the apprenticeship period is the very thing that creates the associate's uncertainty; it arises from the firm's incentive to behave opportunistically at the time of the partnership decision. It is a little like the annual fall ritual in the Peanuts comic strip when Lucy holds the football for Charlie Brown to kick. We all wonder why he continues to make the run at the ball knowing that she will pull it away just when he gets close. If the associate's uncertainty cannot be solved, the apprenticeship solution to the firm's uncertainty is not viable.

\section{A Solution: The Up-or-Out System as a Bonding Device}

Once we recognize that the problem facing the law firm and associate at the time of the initial hire is uncertainty over whether the firm will behave opportunistically at the time of the partnership decision, the problem of organizational design becomes clear. For the apprenticeship period to be a viable response to the firm's uncertainty, the firm must have some bonding mechanism that will assure associates at the time they are hired that the firm will treat them fairly at the time they are considered for partnership.

The most straightforward approach to the problem would be a written contract. The difficulty is that the terms of the partnership decision could not workably be made part of an explicit contract. Consider the usual array of attributes firms describe as desirable in new partners. Traits like good judgment, being a team player, working well with cli-

32. See Greenwald, Adverse Selection in the Labor Market, 53 REv. Econ. STud. 325 (1986) (application of "lemons market" concept to labor market); see also note 70 infra. 
ents, or working hard despite the absence of performance incentives, ${ }^{33}$ are all the sort of amorphous, subjective qualities about which reasonable people can differ but behind which opportunistic people can hide. They cannot be specified with any real clarity, and a decision whether an associate possesses them could not be subject to predictable review by a third party enforcement agent. Thus, a written contract would provide no certainty for the associate, and would introduce substantial uncertainty for the firm. ${ }^{34}$ Indeed, when the terms governing the relationship cannot be specified with sufficient precision to allow predictable formal enforcement, we would expect implicit contracts to be used by organizations. ${ }^{35}$

The implicit contract governing associate promotion is not enforceable by formal legal methods. This does not mean, however, that there are no means to encourage a firm to keep its promise. Rather, it means only that enforcement must be achieved either through reputational sanctions in the employment market or through the design of the relationship itself. ${ }^{36}$

Unfortunately, a reputation model confronts substantial barriers with respect to the implicit contract governing associate career patterns. In a setting without repetitive dealings between the same parties, a reputation model requires that past breaches of the implicit contract be effectively communicated to those who will deal with the breaching party in the future. ${ }^{37}$ The problem in our setting is that the firm's application of the subjective partnership standards to the associate's performance during the apprenticeship period cannot be monitored effectively by third parties. How would other associates and prospective associates know whether Ms. Cleary or Mr. Gottlieb really lacked the requisite skills or whether the firm was behaving opportunistically when it turned them down for partnership? Determining whether a

33. See text accompanying notes 17-18 supra.

34. Where disagreement existed, the upshot of an explicit contract would be to transfer the partnership decision from the firm to a court. Because the subjective criteria for partnership would not significantly restrict the court's discretion, the result inevitably would be substantial uncertainty for the firm with respect to which associates would become partners.

35. From this perspective, for example, the traditional employment-at-will doctrine by which an employer can terminate an employee at any time without cause is not a statement of the terms of an explicit contract-that labor is acquired in a spot market-but, rather, a statement that the implicit contract with respect to the complete terms of employment is not legally enforceable.

36. Plaut stresses that the central concern of the implicit contract literature is enforceability: "The problem is that for any contract to trade labor services, or some other good at some future time $t$, there will always be a motivation for one of the contracting parties to breach the contract whenever the future spot price at $t$ deviates from the contractual price. In the absence of some formal enforcement mechanism (i.e., courts), or informal mechanism (such as a concern for reputation or front-end loading) contracts would never be fulfilled." Plaut, Implicit Contracts in the Absence of Enforcement: Note, 76 AM. EcoN. Rev. 257 (1986).

37. See Bull, Implicit Contracts in the Absence of Enforcement and Risk Aversion, 73 AM. Econ. REv. 658, 659 (1983); Klein \& Leffler, The Role of Market Forces in Assuring Contractual Performance, 89 J. PoL. Econ. 615, 616 (1981); Plaut, supra note 36; Telser, $A$ Theory of Self-Enforcing Agrements, 53 J. Bus. 27 (1980). 
breach has even occurred, let alone effectively communicating that determination to existing or future associates, would be quite difficult. Under these conditions, a reputation model may not be enough. ${ }^{38}$

The unavailability of a reputation model suggests looking to a structural technique-what Oliver Williamson has called a "credible commitment"39 - so that the promise to treat the associate fairly at the time of the partnership decision is self-enforcing through the very design of the relationship. Our thesis is that the up-or-out system, seemingly foolish from the perspective of both the firm and the associate when evaluated at the time the partnership decision is made, provides an effective structural bonding technique when evaluated at the time the associate is initially hired.

To see this, recall precisely how the firm behaves opportunistically at the time of the partnership decision: It seeks to continue earning profits from the associate's efforts by retaining as an associate a lawyer who actually meets the partnership standards. By committing itself to fire anyone who is not made a partner, the firm effectively eliminates its incentive to undertake the very opportunistic behavior that creates the associate's uncertainty. With the up-or-out system in place, the firm cannot manipulate the partnership decision so as to retain in some

38. Professor Steven Shavell has suggested to us circumstances in which a reputation model might work in this context even if associates could not monitor the fairness of the partnership decision with respect to any particular associate. So long as new associates are told at the time they are hired the percentage of associates who will make partner, all that must be observable at the time of the partnership decision is the number of associates who in fact become partners. Although a particular associate still may not know whether he was cheated, it will be apparent if anyone was, and that is all a reputation model requires to operate.

The difficulty with Professor Shavell's analysis is that the partnership decision is more complicated than we have acknowledged up to now. We have stressed the firm's uncertainty about associate ability and the associates' uncertainty about firm opportunism because we believe this dual uncertainty explains the central characteristic of associate career patterns. There is, however, an additional uncertainty present that bears both on the likelihood that a particular associate will become a partner and on the percentage of associates who will become partners: the firm's future success. The implicit contract for associates also reflects some risk-sharing concerning the impact of future downturn in legal business generally, or in the fortunes of the particular firm. Opportunism at the time of the partnership decision is also possible with respect to the allocation of these business risks between the firm and the associate. A firm falsely may represent that its needs, for partners generally or within a particular specialty, have changed since the firm made its representation concerning the percentage of associates who would become partners.

Professor Shavell might respond that a reputation model would work for this type of opportunism as well. A fear of the impact on future hiring would deter the firm from making fewer partners than originally promised. We believe this type of a reputation model is unrealistic. For such a model to work, the terms of the implicit contract must specify the percentage of associates making partner in all possible future states of the world. In addition, the state of the world that exists at the time the partnership decision is made must be observable so that associates can determine the applicable percentage and then compare it to the percentage of associates who in fact become partners. If, as we believe, the actual state of the market for legal services and the competitive position of a particular firm within that market are not observable without substantial noise, a reputation model should not work. For a similar analysis with respect to wage rates, see note 42 infra.

39. O. Williamson, supra note 30, at 163-205; Williamson, Credible Commilments: Using Hostages to Support Exchange, 73 AM. ECON. REv. 519 (1983). 
other capacity the services of an associate whose performance really merits partnership. ${ }^{40}$

In our view, then, the up-or-out system is a structural response to the dual uncertainty confronting the law firm and the associate at the time the associate is hired. It responds to the associate's uncertainty concerning the fairness of the future partnership decision by credibly committing the law firm not to do the only thing that would make later cheating on the initial promise of fair partnership consideration profitable to the firm.41 And by eliminating this incentive for the firm to cheat, the up-or-out system enhances the viability of the apprenticeship period as a solution to the firm's uncertainty about the abilities of the pool of associates it hires. ${ }^{42}$

\section{The Remaining Problem: Associate Risk Aversion}

Although the up-or-out system responds to a major barrier to an apprenticeship solution to the law firm's uncertainty, this solution creates an additional problem. From the associate's perspective, it

40. Moreover, the difficulty of monitoring the firm's partnership decision is no longer a problem once the up-or-out system minimizes the firm's incentive to cheat. Because there is no longer a reason to believe that the firm is not making the partnership decision in good faith, the associate should be less concerned about allowing the decision to be made by the party who both has the best information about the appropriate standards for partnership and the best information about the associate's performance during the apprenticeship period.

41. In our analysis, it is associates' investment in firm-specific human capital during the apprenticeship period that limits their ability to respond to the law firm's cheating. Thus, the presence of significant firm-specific human capital is a central element of the necessity for an up-or-out system. In contrast, Baker, Jensen \& Murphy state that "[u]p-or-out systems work better in situations where the required human capital is general." Baker, Jensen \& Murphy, Compensation and Incentives: Practice vs. Theory, $43 \mathrm{~J}$. Fin. 593, 605 (1988). Although they do not explain their conclusion, their analysis in fact may be largely compatible with our own. If one looks only at the skills associates acquire during apprenticeship, they appear to be general human capital. It is the information asymmetry between the firm and alternative employers in evaluating the quality of the general human capital acquired that, in our analysis, transforms this general human capital into firm-specific human capital. See text accompanying notes 3132 supra.

42. There are other examples of such commitment solutions in the literature. Hart offers one as an alternative to the standard risk-sharing explanation for rigid wage rates. Suppose a company needs to cut either wages or employment as a response to bad times. If employees cannot monitor its claim of bad times, then the company's decision to cut wages, like the law firm's partnership decision, is subject to opportunism. But since the level of employment is related to company profitability, a decision to reduce employment is not subject to the same potential for opportunism as a decision to reduce wages because, unlike reducing wages, reducing employment hurts the company as well as the employees. See Hart, Optimal Labour Contracts under Asymmetric Information: An Introduction, 50 Rev. Econ. STud. 3 (1983).

Lazear uses a commitment approach to deal with employee, rather than employer, opportunism. Employee incentive schemes, whether designed to encourage employees to reveal their abilities or to invest in firm-specific capital, operate by paying the employee less than his marginal product in the period before the employee reveals his ability or completes making an investment in firm-specific capital (or, as in our case, both), and more than his marginal product thereafter. How then does the firm make sure that it does not overpay employees because of the variance in employee career lengths? By accepting mandatory retirement, employees commit themselves to an effective cap on the firm's total obligation for incentive payments. Lazear, supra note 22. 
reduces the risk the firm will cheat on the partnership decision but it increases the risk of investing in firm-specific capital. The option to remain an employee if partnership standards are not met has the desirable characteristic of reducing the risk of the associate's investment in firm-specific human capital. Rather than making an all-or-nothing bet, the associate may prefer the potential of a non-partner position as a consolation prize. The variance of the return to the associate's human capital investment in the firm is thereby reduced without reducing the mean, and the associate is better off as a result.

Giving up this risk-reducing option is costly to the associate. To be sure, by assuring the associate that the partnership decision will be made fairly, the up-or-out system does assure that the associate's investment in firm-specific human capital will be a fair game. But because associates are risk averse, the increase in risk that results from the upor-out system also must be ameliorated for the system to be stable. The next puzzle in explaining the historical dominance of the up-or-out system in corporate law firms is to understand how the system responds to the resulting increase in the risk of the associate's investment.

The traditional analysis of this problem is that the firm offsets the increased risk of an up-or-out system by facilitating outplacement of associates who do not make partner. Because providing an internal consolation prize-non-partner employment-to these associates undermines the credibility of the partnership decision, the increased risk from the up-or-out system is reduced by providing an external consolation prize-for example, a job in the general counsel's office of a client, or a partnership in a less prestigious law firm. For this solution to work, however, it is critical that the law firm minimize the negative implications of an associate not making partner. Put differently, to succeed in outplacement, the firm must overcome the firm-specific character of the associate's human capital investment in revealing her abilities.

The available anecdotal evidence is consistent with this approachoutplacement and minimizing firm-specificity-to reducing the associate's risk. For example, Swaine's discussion of the Cravath experience emphasizes the difficulty of the partnership decision and readily concedes that the partnership decision often errs in the direction of denying partnership to qualified associates:

Obviously not all men competent to be partners can be taken into the firm-for that would make the firm unwieldy. The choice is difficult; factors which control ultimate decisions are intangible; admittedly they are affected by the idiosyncrasies of the existing partners. Mental ability there must be, but in addition, personality, judgment, character. No pretense is made that the ultimate decisions are infallible. Only infrequently have mistakes been made in taking men into the firm; more often, mistakes not so easily remedied have been made in not 
admitting others. ${ }^{43}$

Moreover, if successful outplacement is critical to supporting the up-orout policy, we would expect the firm, in effect, to subsidize the process. For example, a firm might make its unsuccessful associates attractive to other firms by offering an implicit promise to send them referral business. Again, Swaine's description of the practice of the Cravath firm is consistent with this prediction:

Almost without exception, the relations between the Cravath partners and the men who have left the office to compete professionally have remained friendly, and often intimate. . . . Business which such men have been doing while with the firm has frequently been encouraged to continue with them; new business is often referred to former associates. ${ }^{44}$

43. 2 R. Swaine, supra note 14, at 8-9. Statements by Samuel Butler, the current Cravath presiding partner, indicate that Swaine's description of Cravath remains accurate: "We do make it very difficult to become a partner. . . . [We do not make] partners of people who are very good lawyers and absolutely first-class people but are not what we think of as partners in our historical sense ...." Gelling Rid of the Simple Up-or-Out Partner-Associate Structure, supra note 27 , at 30 .

44. 2 R. SwAINE, supra note 14 , at 8 . Anecdotal evidence suggests that referral work after departure continues to accompany Cravath outplacement. From this perspective, because of the need to maintain a continual flow of referral work to power the outplacement process, the firm consciously must decide not to expand to the point where it can undertake all the work that comes to it. The opportunity cost incurred is further evidence that responding to the increased risk resulting from the up-or-out system is costly.

Cravath's experience at outplacement appears from a breakdown of the occupation, as of December 31, 1987, of the 233 lawyers who were associates at Cravath between 1964 and 1974:

Cravath partners*

Number

20

Percent

Partner at a law firm

Of counsel at a law firm

"Associated with" or

"with" a law firm

Sole practice

Name partner in small firm

General counsel, Asst.

General counsel, Senior

Corporate Attorney

Non-legal corporate

Vice President and above

Other corporate

Investment banking

Academic

Self-employed

Other

TOTAL

\begin{tabular}{|c|c|c|}
\hline & Number & Percent \\
\hline & 20 & 8.6 \\
\hline \multicolumn{3}{|l|}{86} \\
\hline 4 & 90 & 38.6 \\
\hline 7 & & 3.0 \\
\hline \multicolumn{3}{|l|}{11} \\
\hline \multirow[t]{2}{*}{$\underline{5}$} & 16 & 6.9 \\
\hline & 39 & 16.7 \\
\hline \multicolumn{3}{|l|}{18} \\
\hline \multirow[t]{5}{*}{10} & 33 & 14.2 \\
\hline & 8 & 3.4 \\
\hline & 6 & 2.6 \\
\hline & 14 & 6.0 \\
\hline & 233 & 100.0 \\
\hline
\end{tabular}

* Includes one partner who left Cravath for investment banking. Source: R. SwaINE, supra note 14, (Supp. 1964-1974). 
What happens, however, when outplacement is not available to reduce the increased risk to associates resulting from using the up-or-out system to assure the fairness of the partnership decision? ${ }^{45}$ An alternative way to reduce this risk is simply to increase the likelihood of making partner. Understanding how firms choose between outplacement, an external approach, and increasing the likelihood of making partner, an internal approach, poses an additional puzzle. Compared to outplacement, increasing the likelihood of making partner seems to be a very expensive way to reduce associate risk. And this puzzle is further complicated by the unusual pattern of firms that nonetheless select the more expensive approach. ${ }^{46}$

A useful measure of a firm's success in reducing associate risk by outplacement rather than by an increased likelihood of making partner is its leverage: the ratio of associates to partners. The higher the ratio, the lower the likelihood of becoming a partner, and the higher the internal risk to the associate's human capital. ${ }^{47}$ Therefore, the higher the firm's leverage, the more successful must be the firm's efforts at reduc-

Maister notes that non-legal professional service firms that enforce an up-or-out system also stress outplacement. McKinsey [a management consulting firm] and Arthur Andersen [a Big Eight accounting firm]

work actively to place their alumni/ae in good positions preferably with favored clients. .. In part, due to the "caring" approach taken to junior staff, one-firm firms are able to achieve a very profitable high-leverage strategy (i.e., high ratio of junior to senior staff) without excessive pressures for growth to provide promotion opportunities.

Maister, The One-Firm Firm: What Makes It Successful, SlodN MGMr. Rev., Fall 1985, at 3, 9 (emphasis omitted).

45. The pattern in other settings in which an up-or-out system is dominant reinforces our conclusion that the system's stability requires some means to reduce the risk that results from eliminating the consolation prize of continued employment for those who are not promoted. In the military, for example, the availability of early retirement at full pay provides a risk reducing consolation prize. If the time at which the up-or-out decision is made corresponds to the availability of early retirement, the risk of non-promotion is very significantly hedged.

In academia, reduced informational asymmetry between current and alternative employers concerning the faculty member's ability may make the problem less important. Recall that one barrier to outplacement by a law firm, overcome by techniques like those ascribed to the Cravath firm, is the negative inference drawn by potential employers from the very fact that the associate was not promoted. In the law firm setting, the barrier is particularly high because it is difficult for a potential employer to evaluate independently the associate's abilities; knowledge about the associate's real abilities is a firm-specific asset. See text accompanying note 31 supra. Because the principal measure of an academic's abilities-published scholarship — can be more readily evaluated by alternative employers, the additional risk imposed by the up-or-out system, called tenure in an academic setting, is less significant.

46. The need to offset the increased risk resulting from an up-or-out system does not depend on the associates' accurately assessing their likelihood of making partner. Even if they systematically overestimate their chances because of some cognitive bias, see Tversky \& Kahneman, Judgment Under Uncertainty: Heuristics and Biases, in JUDGMENT UNDER UNCERTAINTY: Heuristics and Biases 3 (D. Kahneman, P. Slovic \& A. Tversky eds. 1982), the system still increases the risk.

47. This assumes the ratio remains constant over time. In a period of growth, a firm's overall leverage may increase even though the percentage of each new group of associates who ultimately become partners remains the same. 
ing associate risk by external means. ${ }^{48}$

The puzzling pattern of firm choice between external and internal approaches to reducing associate risk appears when we recognize two empirical patterns. First, firm leverage is directly related to firm profit: the higher the firm's leverage, the higher the firm's per partner profit. ${ }^{49}$ When one outlier is eliminated, our regression analysis of data from the American Lawyer's compilation of the one hundred most successful corporate law firms for 1987 discloses that differences in leverage explain 34.3 percent of the differences among firms in per partner profitability. ${ }^{50}$ Second, the degree of firm leverage appears to be determined, in part, geographically: the same data indicate that among these one hundred firms, those based in New York City had an average associate/ partner ratio of 2.55, while those based outside New York had an average ratio of only 1.66; the leverage of New York firms was greater by some 54 percent. ${ }^{51}$ If an important determinant of per partner profit is leverage, and if leverage seems to be predicted by geographical location, what has kept firms outside New York from increasing their partners' profit by increasing their leverage?

One hypothesis for why firms outside New York have lower ratiosdespite the clear relation between associate-partner ratio and profitsderives from understanding the impact of leverage on the stability of the up-or-out system. High leverage (and a low likelihood of making partner) requires the ability to reduce the risk for associates by successful outplacement. It is possible that the concentration of corporate activity in New York-for example, the presence of corporate headquarters and, therefore, corporate counsel positions-facilitates outplacement by New York firms as compared to firms located elsewhere. This would allow New York firms to more easily reduce the risk for associates created by the up-or-out system externally, through outplacement, while firms in other geographic areas would be left to reducing the risk of the associates' human capital internally, through an

48. This would be necessary just to make the return on the associate's investment a fair game: As the likelihood of winning goes down, the size of the prize must go up for even riskneutral participants to be willing to play.

49. The Am Law 100, AM. Law., Mgmt. Rep., July-Aug., 1988, at 44.

50. The outlier is Wachtel, Lipton, Rosen \& Katz, a firm specializing in hostile takeover work. In 1987, Wachtel was reported to have an average profit per partner of $\$ 1,405,000-$ the top in the nation-although its ratio of associates per partner was only 1.05. This firm bills for takeover work on a transaction, rather than on a per-hour, basis, which significantly reduces the importance of leverage. If Wachtel, Lipton is included in the regression, differences in leverage explain $20.9 \%$ of the differences among firms in per-partner profits.

51. This analysis is consistent with reported data that a new associate's likelihood of partnership in a large corporate law firm is lower in New York. Over the period 1970-1977, new associates joining large Chicago firms had a $48.8 \%$ chance of making partner, while those joining large New York City firms had only a $22.8 \%$ chance of partnership. Spurr, How the Market Solves an Assignment Problem: The Matching of Lawyers with Legal Claims, $5 \mathrm{~J}$. LAB. ECON. 502, 522 (1987). Accord R. NELSON, supra note 14, at 138, Table 7 (reporting departure rates for associates at 19 prominent Chicago firms). 
increased likelihood of making partner. ${ }^{52}$

This picture is one of varied responses to associate risk aversion depending on the real alternatives available to the firm. When a firm is successful at outplacement, the leverage maintained by the firm can be higher than that of other firms, whether in other cities or within the same city, with less successful outplacement. ${ }^{53}$ In contrast, when a firm is less successful at outplacement, associate risk must be reduced by increasing the likelihood of partnership and, as a result, decreasing the per partner profitability of the firm.

\section{Why Are Associate Career Patterns Changing?}

The bonding explanation for the historical dominance of the up-orout system leaves one observed pattern unexplained: Recently there has been a significant increase both in criticism of the system and in the number of firms that, in one fashion or another, have deviated from the practice of firing all associates who are not made partners. ${ }^{54}$ To fully understand the up-or-out system, we must be able to account for changes in the environment that have caused the movement away from it. And to evaluate fully the bonding explanation for the dominance of the up-or-out system, we also must be able to account for how these changes alter the conditions that required bonding in the first place.

Three different, though not mutually exclusive, types of changes can explain this incipient shift in associate career patterns. First, changes in the relationship among partners are changing the criteria used to evaluate a lawyer's performance, whether as an associate or as a partner. Second, a substantial increase in the demand for associates has re-

52. One approach to testing the hypothesis would be to examine, by large metropolitan area, the ratio of sophisticated legal jobs outside corporate law firms to the number of lawyers in corporate law firms. The hypothesis predicts that this ratio will vary directly with firm leverage.

Outplacement could also be accomplished through placement at other law firms. Available data suggest this avenue may also be geographically distributed. Nelson reports that only $5 \%$ of associates who leave the four prominent Chicago firms he studies end up with a large law firm. R. NelsoN, supra note 14, at 143. In contrast, between 1964 and 1974, some $3.3 \%$ of Cravath associates who did not make partner at Cravath became partners at Skadden, Arps alone. R. SwaINE, supra note 14, Supp. 1964-1974.

53. Thus, the hypothesis can be extended to explain variance in leverage among firms within a single metropolitan area.

54. See, e.g., Blum \& Lobaco, When Associates Don't Make Partner, Cal. Law., Jan.Feb. 1988, at 51; Brill, Living Dangerously, AM. LAw., Nov. 1986, at 1; Carbonara, Gaston Snow Reinvents The Two-Tier System, AM. LAW., Oct. 1987, at 14; Freeman, Alternatives to the Old Up or Out, Cal. LAw., Dec. 1987, at 44; Getting Rid of the Simple Up-or-Out Partner Associate Structure, supra note 27; Quade, Not Quite Partner, A.B.A. J., Apr. 1984, at 30; Singer, Senior Attorney Programs: Half a Loaf, Am. LAw., Jan.-Feb. 1987, at 12; Snider, Inside the Megafirms, Cal. LAw., Sept. 1987, at 32; Galante, Meet the Permanent Associate, Nat'l L.J., Oct. 24, 1983, at 1, col. 5; Galante, Firms Look Closer at How to Create Lawyer Categories, L.A. Daily J., Aug. 22, 1983, at 1, col. 6; Hallam, Big Firms Search for Alternatives to Traditional Form, L.A. Daily J., Mar. 18, 1983, at 1, col. 6; Graham, New "Senior Attomey" Program Draws Attention at Davis Polk, Legal Times, Feb. 28, 1983, at 3, col. 1; Glasser, Firm Explores New Partnership Category, Legal Times, Feb. 14, 1983, at 12, col. 2. 
quired that the hiring pool be expanded beyond top graduates of elite national law schools. Third, a general reduction in the importance of firm-specific human capital for associates may allow the employment market to provide the protection previously provided by the up-or-out system.

\section{A. Changing Criteria for Partnership}

The linchpin of our explanation for the up-or-out system as a means by which a law firm bonds itself not to cheat on the partnership decision is the associate's inability to monitor directly the fairness of that decision. Suppose the standards for partnership were purely quantitativefor example, hours worked multiplied by fees actually collected. Then the associate easily could monitor the partnership decision; all that would be necessary would be access to the firm's timekeeping and billing records. ${ }^{55}$ To be sure, the firm could cook the books to achieve an opportunistic result even with a quantitatively mechanistic formula. But the records involved are central to the firm's operation, so that the management cost to the firm of intentionally inaccurate records would be high. Moreover, their very importance makes it unlikely that a separate, accurate set could be kept secretly for management purposes while the public set was skewed to support opportunistic partnership decisions. ${ }^{56}$

Thus, to the extent that the standards for partnership become more observable, direct associate monitoring can replace the bonding function of the up-or-out system as a means of assuring that the firm makes the partnership decision fairly. The question, then, is what might motivate such a shift in the standards used for the partnership decision. ${ }^{57}$

One obvious reason may be a shift that is taking place in the methods by which many law firms divide their profits. An important reason for subjective partnership criteria is a sharing approach to income division. ${ }^{58} \mathrm{~A}$ firm that divides its income by a method that emphasizes risk-

55. Cf. McChesney, Team Production, Monitoring, and Profit Sharing in the Law Firms: An Alternative Hypothesis, $11 \mathrm{~J}$. LEGAL STUD. 379 (1982) (documenting the pervasive monitoring by law firms of hours worked by individual lawyers).

56. There are other barriers as well. First, the firm does not have exclusive access to the data underlying the records. At least with respect to hours worked, an associate is capable of keeping her own records as a check on the accuracy of the firm's records, behavior that is more likely the more important are the data to the associate's future. If this information were shared among associates, the firm's data could be duplicated by the associates. Second, because the firm presumably bases the partnership decision on an associate's performance over a number of years, opportunistic record keeping requires that the firm be able to identify those associates who will be the object of this behavior a significant time before the partnership decision is to be made. To this extent, however, opportunistic manipulation of the underlying data conflicts with the very point of the apprenticeship period-to allow associates to reveal their true abilities.

57. See, e.g., Carbonara, supra note 54 (simultaneous with its adoption of a complex twotier partnership structure, Gaston Snow \& Ely Bartlett adopted for the first time written partnership standards that emphasized business generation, a more quantitative criterion).

58. See Gilson \& Mnookin, supra note 1 , at 374-80. 
sharing to the virtual exclusion of incentives needs partners who, because of their personal characteristics, will not take advantage of the incentive to grab, shirk, or leave that a sharing approach creates. 59 The criteria which identify associates that have the desired personal characteristics are unavoidably subjective and, therefore, unobservable by third parties. Thus, the firm's method of dividing profits influences what standards govern the partnership decision, the unobservability of which creates the potential for the opportunism to which the up-or-out system responds.

Now consider what happens when, as appears to be increasingly the case, ${ }^{60}$ the firm changes its method of dividing profits from a sharing model to a productivity approach in which profits are divided based on an effort to measure the actual contribution of each partner. As the formula for measuring productivity becomes more mechanistic-emphasizing, for example, such quantifiable factors as hours worked, amounts billed and clients attracted ${ }^{61}$ - the need for subjective partnership standards diminishes because the damage that results from making a "wrong" partnership decision is reduced. If a partner does not work out in a firm with a productivity approach to dividing profits, the unproductive partner receives only what he has "earned," an amount presumably substantially lower than more productive partners receive, rather than nonetheless receiving the same amount as more productive partners as in a sharing firm. Indeed, at the extreme, a mechanistic approach to income division can eliminate the need for an apprenticeship period and even eliminate the concept of partnership. Recall that the apprenticeship period is a response to the firm's uncertainty about the quality of the associates it has hired. An alternative way to eliminate that uncertainty is to eliminate its consequences. If associates' productivity can be measured so that they are never paid more than they are worth, uncertainty about their ability at the time they are hired is no longer important, and the apprenticeship period that defines the functional distinction between partner and associates is no longer necessary. Then we simply might make all lawyers partners (or

59. Our earlier article described the three problems with a sharing approach to dividing profits. It may lead to "shirking, a partner's failure to do his 'fair share' of the work; grabbing, a partner's extraction of a larger than previousiy agreed share of firm profits by threatening to depart; and leaving, a partner's departure from the firm with clients and business in tow." Id. at 321 .

60. See id. at 315 n.6. Los Angeles's Tuttle \& Taylor is a recent example. See Orey, Heller Erman Nabs Tuttle Trio, AM. LAw., Apr. 1988, at 14.

61. These are not as easy to quantify as may at first appear. For example, with respect to client attraction, does a client belong to the partner who brought the client in the door or the partner who, by doing the work, keeps the client from leaving? For a discussion of the difficulty in specifying productivity formulas and the risk of creating perverse incentives, see Gilson \& Mnookin, supra note 1, at 349-52. There are, however, ways to approach this issue. If bringing in the client initially works Williamson's fundamental transformation from a competitive market to bilateral monopoly, see O. Williamson, supra note 30, at 61-63, then the importance of attracting the client, as opposed to servicing the client, goes up. In all events, however, an accurate determination is likely to be quite context specific. 
associates). 62

Thus, as the formula for income division becomes more mechanistic, so too can the standards for partnership. Such standards would enable associates to monitor more effectively the fairness of the partnership decision. In this setting, preventing the firm from behaving opportunistically in making the partnership decision no longer requires the up-or-out system. Indeed, in this setting, the up-or-out system actually would present the puzzle with which we started: it would work to neither party's advantage. A movement away from the system, to allow both the firm and its associates to benefit from an option for associates to remain in that capacity, would follow naturally. ${ }^{63}$

\section{B. Increased Demand for Associates}

Another explanation for the movement away from the up-or-out system does not depend on a change in the manner in which the firm divides its profits. The business of major corporate law firms and, hence, their demand for associates, appears to be growing so fast ${ }^{64}$ that the traditional sources of new associates-elite national law schoolsno longer provide an adequate supply. The least restrictive version of the familiar story told by major law firm recruiters is that their firms hire as new associates only law students in the top half of their class at, say, the top twenty law schools. ${ }^{65}$ It now appears that this source of associate supply does not meet current firm demand. One commenta-

62. Just such an approach-abolishing the concept of partner (or, instead, of associate) - was recently suggested by the former managing partner of Morrison \& Foerster, a large national law firm. See Mode \& Raven, Associate Leverage is Doomed, Am. Law., Nov. 1985, at 10, 12; Brill, supra note 54, at 1, 30; see also Stuart, Anderson Russell's Classless Society, AM. LAw., Dec. 1986, at 10 (description of an "all partner" form).

The ability to accurately measure an associate's productivity does not eliminate entirely the need for some screening by the firm. If there is the potential that some associates in the pool are so bad that they will expose the firm to affirmative loss-for example, through damages for malpractice or through loss of clients-then paying even a zero wage does not fully protect the firm. It may be possible, however, to eliminate this risk through selective criteria for initial hiring.

63. Recognizing that the unobservability of the partnership decision creates the need for the up-or-out system as a bonding device suggests another approach to increasing the associates' monitoring ability. If a firm can identify one or more associates who are very likely to be made partners, allowing those associates to participate in the partnership decision processperhaps by serving on the relevant committee and attending the partnership meeting at which the decision is made-may increase substantially the extent to which associates can directly monitor the decision. To be sure, the solution is not complete because of the risk that the associate monitors either may be co-opted (by the promise of, or a threat to, their future partnerships) or fooled, but the ability of the firm to behave opportunistically still would be significantly constrained. We are grateful to Marshall Small for calling this point to our attention.

64. See, e.g., Busy Law Firms' Profits Leap. N.Y. Times, July 2, 1987, at D1, col. 3; Gray, Law Firms' Btg Fee Hikes Reflect Higher Pay and Booming Business, Wall St. J., Mar. 19, 1987, at 37, col. 4.

65. Those familiar with the interviewing practices of elite firms as recently as five years ago will object that typically such firms hired associates from far fewer than twenty schools. As will be apparent, this observation only underscores the explanation offered in the text. 
tor recently calculated that in 1986 , a total of 6080 students received law degrees from schools comprising his top-twenty list, resulting in 3040 graduates in the top half of their classes. ${ }^{66} \mathrm{He}$ then calculated that 4807 new associates began working for the top 250 law firms that year, a number that exceeded the supply of top-half, top-twenty graduates by some 58 percent.

The clear implication of this calculation is that major firms may have begun to hire from a different ${ }^{67}$ and perhaps less capable ${ }^{68}$ pool of associates than in the past. And the question for associate career patterns is whether the law firms' traditional up-or-out system can accommodate the impact of an influx of what may be higher risk associates on two of its critical elements: the screening function of the apprenticeship period and successful outplacement of associates who do not become partners.

Expanded recruitment, both in the numbers of associates hired and the number of schools from which they are hired, has three effects that may strain the firm's capacity to evaluate during the apprenticeship period all of the associates that it hires. First, the size of the pool of associates whose abilities must be evaluated increases without, even in the medium run, an increase in the number of partners making the evaluations. Increased leverage simply increases the burden on the evaluative process. Second, a decrease in the quality of the pool-a decrease in the mean and an increase in the variance of the abilities of new associates-may increase the difficulty of making evaluations. More effort may be necessary to screen effectively. Finally, deterioration in the law firm's screening can affect not only the new lower quality associates, but also the traditional higher quality associates. Unless some special accommodation is made, a possible result is that more mistakes are made with respect to both groups, thereby decreasing the firm's attraction to traditional associates, ${ }^{69}$ and creating the potential for a "lemon's"

66. Bernstein, Does a Hiring Crisis Threaten the Profession?, Nat'l L.J., Dec. 28, 1987, at 20, col. 2. The author had the good sense to decline to identify the composition of his top twenty. Robert Raven, former managing partner of Morrison \& Foerster, has a considerably more pessimistic estimate of the supply of desirable associates: "Depending on how many schools you go to and how deep you go into the class, there's a pool of about 1,200 to 1,400 people out there that you would like to confine your offers to." Getting Rid of the Simple Up-orOut Partner-Associate Structure, supra note 27, at 29.

67. See Snider, supra note 54, at 34-35 (describing expanded law school recruiting and hiring by major California firms); Jensen, Perks: When High Salaries Aren't Enough, Nat'l L.J., June 22, 1987, at 1, col. 1 (describing expanded law school recruiting and hiring by Morgan, Lewis \& Bockius; Dewey, Ballantine, Bushby, Palmer \& Wood; and Brown \& Wood).

68. That the pool is different need not necessarily mean that its members are less capable. If demand for admission to law school has increased along with the demand for new lawyers, the quality of applicant to some nonelite schools may have increased to a level previously found only at elite schools. A rough test of this hypothesis might be to compare the LSAT scores and GPAs of, for example, the current class of associates with that hired ten years ago.

69. From the perspective of traditional associates, the increase in the likelihood of a mistake serves to increase the risk associated with their human capital, and makes working for that firm less desirable. 
market. ${ }^{70}$

Just as the increase in the number of associates entering the apprenticeship period may hamper the firm's ability to screen associates successfully, so the increase in the number of associates exiting the apprenticeship period-those who do not make partner-may hamper the firm's ability to provide outplacement for unsuccessful associates. An increase in the supply and a decrease in the quality of associates to be placed unavoidably affects demand.

Outplacement also may be hampered if the variance in the quality of the new pool of associates is higher. Recall that to maximize its capacity to place associates who do not make partner, the firm should give the appearance that the partnership decision is so selective as perhaps to be arbitrary, so that being turned down for partnership is not a negative signal of the unsuccessful associate's ability. To the extent the change in the pool of associates hired makes this story less believable, outplacement becomes more difficult. And this, in turn, makes less effective the firm's efforts to offset the increased risk to the associate resulting from the up-or-out system's elimination of the permanent associate category.

Moving away somewhat from the up-or-out system responds to the problems caused by increasing the size and the variance, and decreasing the average quality, of the pool of associates hired. But responding to these problems requires a very different kind of move than that suggested by the increased ability to monitor explanation discussed in the previous section. Now the need is to expand the number of associates without diluting the quality of the apprenticeship period's operationno increase in screening error and no decrease in outplacement success-with respect to the traditional pool of new associates from which, presumably, new partners will come.

This might be accomplished by dividing associates into two categories at the time they are hired. Those in the category drawn from the traditional pool of associates are treated as associates in an up-or-out system always have been: their performance during the apprenticeship period is evaluated carefully, and those who do not meet the partnership standard are placed elsewhere. The associates drawn from the new, non-traditional sources are advised from the outset that they will never be considered for partnership, thereby imposing no additional burden on the apprenticeship period's screening function. And because the new category of associates is clearly designated as such from the outset, there is limited risk of compromising the firm's ability to place associates from the traditional category.

70. In a lemon's market, high quality producers are unable to distinguish their products from those of low quality producers. High quality products therefore command no higher price than low quality products and, as a result, only low quality products are produced. See Akerlof, The Market for "Lemons": Quality Uncertainly and the Market Mechanism, 84 Q.J. ECON. $488,489-90$ (1970). 
Variations on this theme-an identifiable group of associates who will not be considered for partnership-are also possible. Contract lawyers, the equivalent of legal temps, serve the same function. ${ }^{71}$ One also can imagine implicit tracking within a firm so that some associates are given work that provides the opportunity to show that they have partnership qualities, while others are given work, like document discovery in a large antitrust case, that does not burden the screening function. ${ }^{72}$

\section{The Diminished Importance of Firm-Specific Human Capital}

In recent years, the practice of corporate law firms has changed from one characterized by longstanding relationships with continuing clients to one in which one-shot transactional work for a succession of clients is of growing importance. ${ }^{73}$ The result has been increased emphasis on the technical specialization necessary to support a transactional practice, rather than on developing the detailed knowledge of and relationships with longstanding firm clients that are at the core of traditional practice. ${ }^{74}$ In contrast to more subjective characteristics that have been important to the partnership decision, ${ }^{75}$ specialized technical skills can be more easily evaluated by competing firms even if the associate's present employer does not cooperate. As a result, such technical skills tend not to be plagued by substantial information asymmetries, thereby reducing the firm-specific aspect of these skills. The

71. Interestingly, at the same time this phenomenon is growing in importance, see Berkman, Temporarily Yours: Associates for Hire, AM. LAw., Mar. 1988, at 24; 'Contract Associates', A.B.A. J., Feb. 1, 1987, at 24, agencies that provide contract lawyers have come under attack as being engaged in the unauthorized practice of law, see Zeldis, 'Temp' Agencies Up in Arms over City Bar Ethics Ruling, N.Y.L.J., Apr. 8, 1988, at 1, col. 3; Lawyers Wamed Against Role in Job Placement Agencies, N.Y.L.J., Apr. 6, 1988, at 1, col. 3.

72. To the extent the implicit tracking system is not observable from outside the firm, outplacement can be extended to some of these associates as well, thereby allowing the firm to attract better quality second-tier associates.

Nelson provides data that suggest how an implicit tracking system might arise. He reports that the percentage of lawyers from local (the least prestigious) law schools hired during 1975-1980 by the four prominent Chicago firms he studied more than doubled compared to the percentage hired from this source prior to 1970 . R. NELson, supra note 14, at 132, Table 5. At the same time, however, it appears that graduates of local law schools have only about a 25 percent chance of making partner while the chance of partnership for all associates (including local law school graduates) is close to 50 percent. Id. at 138, Table 7 (comparing departure rates of classes hired in 1971 whose members would already have come up for partnership). Assuming that monitoring resources are scarce within a law firm, it is easy to see how they might be allocated differentially between populations with dramatically different likelihoods of success, resulting in an implicit second track for local law school graduates. For this purpose, of course, it is irrelevant whether the initial lower success rate of local law school graduates results from lower ability or simply bias. Once monitoring resources are allocated differentially, the group that receives less of the resource will be less successful regardless of the actual distribution of talent.

73. See Gilson \& Mnookin, supra note 1, at 384-86; R. NELson, supra note 14, at 54-59; M. Galanter \& T. Palay, supra note 14 , at 52-54.

74. See Gilson \& Mnookin, supra note 1 , at 358-60.

75. See text accompanying note 17 supra. 
outcome is to reduce substantially the firm's ability to act opportunistically with respect to its associates. So long as other firms need the technical skills a particular associate possesses, the market increasingly can provide the protection previously provided by the up-or-out system.

\section{Evaluation}

Each of the explanations for the observed movement away from the up-or-out system is consistent both with observed changes in the firm's environment and, happily, with a bonding explanation for the historical dominance of the up-or-out system. The three explanations, however, are not mutually exclusive and, indeed, predict different kinds of movements away from the up-or-out system. Two of the explanations, the changing criteria for partnership and the diminished importance of firm-specific human capital, predict new categories of lawyers identified only after they complete the apprenticeship period and do not meet partnership standards. The increased demand explanation, in contrast, predicts new categories of nonpartner lawyers so identified from the time they are initially hired. In fact, we observe both kinds of movements. A significant number of firms have created new categories of positions for associates who, following completion of the associate period, are not promoted to partner. ${ }^{76}$ In contrast, Jones, Day, Reavis \& Pogue, one of the nation's largest firms, ${ }^{77}$ has created a category of associates, currently numbering forty-three, who are hired with the understanding that they will never be considered for partnership, and the concept is described as "on lots of law firms' retreat agendas."78

The puzzle that remains is to understand the firm characteristics that lead to one or the other approach. At this juncture, however, we can do no more than identify a number of testable propositions. The changing criteria for partnership explanation predicts that firms which create a new position for associates who do not make partner will divide their income on a productivity basis and likely will have moved to that method recently from a method more concerned with risk-sharing than incentives. The increased demand explanation, because it contemplates firms hiring associates of lower mean ability and higher variance than in the past, predicts that such firms will have increasing amounts of legal work of the sort that can be competently accomplished by lower quality lawyers. Finally, the diminished importance of the firm-specific human capital explanation predicts that the practice of firms which abandon the up-or-out policy will be heavily transactional.

76. See sources cited in note 54 supra.

77. As of September 1987, Jones Day had 727 lawyers. Getting Rid of the Simple Up-Or-Out Pariner-Associate Siructure, supra note 27 , at 31.

78. Zeldis, Staff Attorneys Catching On?, Nat'l L.J., May 2, 1988, at 2, col. 1. Consistent with our analysis, the Jones Day associates are described as coming from second-tier law schools. Paul, Weiss, Rifkind, Wharton \& Garrison also is reported to have initiated such a program. Id. 


\section{Conclusion}

In this article, we have attempted two tasks. First, we tried to explain the efficiency characteristics of the up-or-out system, the peculiar capital budgeting process by which corporate law firms traditionally have acquired and retained human capital. We started with the puzzle that the up-or-out system seemed to be in neither party's best interest. From the firm's perspective, a valuable resource was lost by firing associates who did not quite meet partnership standards. From the associate's perspective, eliminating the possibility of remaining an associate increased the risk of the associate's human capital investment. The puzzle was unraveled by recognizing the dual uncertainty that exists at the time the associate is initially hired. The response to the firm's uncertainty-how to distinguish among a heterogeneous pool of associates-was an apprenticeship period for which associates were compensated by the promise of partnership for those who met the standards. But this very response created the associates' uncertainty. Because the partnership standards were unobservable, the associate could not monitor the firm's fairness in evaluating her performance. This created the potential for the firm to behave opportunistically with respect to the partnership decision by keeping as an associate one who had really satisfied the standards for promotion. The up-or-out system serves to bond the firm's promise of a fair evaluation by eliminating access to the firm's principal means of behaving opportunistically: denying partnership to keep the associate working for the firm's account.

Second, we examined the influence of risk-sharing and incentives on organizational structure when, as in service industries, the dominant firm input shifts from industrial to human capital. In this respect, law firms are interesting organizations. They are, in many ways, the quintessential service firms-their only significant input is human capital. It is the dominance of human capital, we believe, that is the major determinant of law firm organization. So, because human capital is difficult to diversify, the need for risk-sharing is an important influence on organizational structure. Nonproductivity-based methods of dividing profit reduce the risk of partners' human capital investment. ${ }^{79}$ Emphasis on outplacement or, where that is not possible, increased likelihood of becoming a partner, reduces the risk of associates' human capital investment. ${ }^{80}$ And because human capital is susceptible to opportunism, the need for incentives is the second major influence on law firm organization. The development of firm-specific capital protects the firms against some partners grabbing, shirking, or leaving. ${ }^{81}$ The up-or-out system protects associates against the firm cheating on its promise of a fair partnership decision at the close of an associate's apprenticeship

79. See Gilson \& Mnookin, supra note 1, at 341-46.

80. See text accompanying notes 42-52 supra.

81. See Gilson \& Mnookin, supra note 1, at 353-71. 
period. ${ }^{82}$

Identifying risk-sharing and incentives as the two central influences on law firm organization should sound a familiar note to economists. The shape of the relations that emerge from the conflict between risksharing and incentives has been the primary focus of the economic theory of agency. ${ }^{83}$ And the conditions that create the potential for opportunism and the use of organizational structure to control that potential have been a primary focus of transaction cost economics. ${ }^{84}$ Two things flow, it seems to us, from recognizing this congruence between real institutions and the leading edge of economic theory. First, it underscores the value of both agency and transaction cost analysis to positive analysis, to understanding why the world is as we find it. Second, it holds out the promise of improving our capacity for normative analysis, for designing organizations that operate more effectively.

82. See text accompanying notes $39-40$ supra.

83. See Jensen, Organizalion Theory and Methodology, 58 Accr. Rev. 319, 334-36 (1983) (distinguishing between the principal-agent and positive theory of agency literatures).

84. See, e.g., Williamson, Corporate Finance and Corporate Governance, 43 J. Frn. 567, 567-75 (1988) (distinguishing between the economic theory of agency and transaction-cost economics). 